\begin{tabular}{c} 
Brazilian Journal \\
of Chemical \\
Engineering \\
\hline
\end{tabular}

ISSN 0104-6632

Printed in Brazil

www.abeq.org.br/bjche

Vol. 29, No. 03, pp. 653 - 664, July - September, 2012

\title{
VISCOSITIES AND VISCOSITY DEVIATIONS OF BINARY MIXTURES OF BIODIESEL + PETRODIESEL (OR N-HEXADECANE) AT DIFFERENT TEMPERATURES
}

\author{
F. M. R. Mesquita, F. X. Feitosa, F. R. do Carmo, R. S. de Santiago-Aguiar and \\ H. B. de Sant'Ana* \\ Grupo de Pesquisa em Termofluidodinâmica Aplicada, Departamento de Engenharia Química, \\ Centro de Tecnologia, Phone: + (55) (85) 3366-9611, Fax: + (55) (85) 3366-9610, Universidade Federal do Ceará, \\ Campus do Pici, Bloco 709, CEP: 60455-760, Fortaleza - CE, Brazil. \\ E-mail: fmrm03@gmail.com; E-mail: filipexfeitosa@hotmail.com; E-mail: frederico-rc@hotmail.com; \\ E-mail: rilvia@ufc.br; ${ }^{*} E-m a i l:$ hbs@ufc.br
}

(Submitted: July 23, 2011 ; Revised: November 7, 2011 ; Accepted: January 13, 2012)

\begin{abstract}
Viscosities of four binaries mixtures [soybean biodiesel + diesel oil (or n-hexadecane) and coconut biodiesel + diesel oil (or $\mathrm{n}$-hexadecane)] have been determined at $\mathrm{T}=(293.15,313.15,333.15,353.15$, 373.15) $\mathrm{K}$ and atmospheric pressure over the entire composition range. Experimental data were fitted to the Andrade equation and the adjustable parameters and the standard deviations between experimental and calculated values were estimated. From the experimental data, the viscosity deviations, $\Delta \eta$, were calculated by using the Redlich-Kister polynomial equation. The comparison between experimental data determined in this work and four predictive methods used for the estimation of viscosities of biodiesel fuels (based on their fatty acid composition) is discussed.
\end{abstract}

Keywords: Viscosity; Binary Mixtures; Biodiesel; Petrodiesel.

\section{INTRODUCTION}

In recent years, the decreasing oil supply, associated with the objective of a clean energy economy, has become a major issue in the search for alternative energy sources. The search for alternative energy sources has led to the development of different technologies for fuel production from biomass, such as biodiesel.

Among the raw materials used in the production of biodiesel, vegetable oils from soybean seeds, palm trees and cotton seeds are widely used. Soybean seeds and coconut are the most commonly used raw materials for the production of biodiesel in Brazil (Boletim Mensal do Biodiesel/ANP, 2011). Biodiesel presents advantages related to its use to replace a proportion of petroleum diesel in compression ignition engines in order to achieve a significant emission reduction. In Brazil, since January 2010, 5\% of biodiesel is used in commercial diesel oil (B5).

Biodiesel can be obtained by the transesterification reaction of vegetable oils or other materials largely composed of triacylglycerols, such as animal fats or used frying oils, with monohydric alcohols to give the corresponding mono-alkyl esters (Knothe and van Gerpen, 2009).

Because biodiesel is completely miscible with diesel oil, the blending of both fuels in any proportion is possible and recommended in order to improve fuel qualities. However, the differences in

*To whom correspondence should be addressed 
the chemical nature of biodiesel and diesel oil may cause differences in the physicochemical properties of the blend, affecting engine performance and pollutant emissions (Benjumea et al., 2008; Jha et al., 2008). For this reason, the major concerns when dealing with biodiesel + diesel oil mixtures are the knowledge of thermodynamics and transport properties, such as viscosity and its dependence on composition and temperature. It should also be mentioned that viscosity influences the atomization quality, the size of the fuel drops and the quality of combustion (Encinar et al., 2005; Tate et al., 2006).

In this context, the aim of this study is to investigate the viscosity behavior of four binary mixtures [soybean biodiesel + diesel oil (or n-hexadecane) and coconut biodiesel + diesel oil (or $\mathrm{n}$-hexadecane $)]$ at $\mathrm{T}=(293.15,313.15,333.15,353.15$, 373.15) $\mathrm{K}$ and atmospheric pressure. It is important to notice that, although hexadecane is a slightly larger molecule than the average for diesel oil, it is commonly used as a reference molecule for modeling diesel oil thermodynamic properties and usually used as a reference molecule in lumping procedures. For this reason, the viscosity of biodiesel $(+$ diesel oil or $+n$-hexadecane) mixtures was experimentally determined as previously done for density (Mesquita et al., 2011). From the experimental data, the viscosity deviations, $\Delta \eta$, were derived. The models proposed by Yuan (Yuan et al., 2009), and Revised Yuan (Pratas et al., 2010) and do Carmo (do Carmo et al., 2012) were used in order to predict the viscosity data.

\section{EXPERIMENTAL SECTION}

\section{Chemicals}

N-Hexadecane obtained from Merck was used without further purification. Its mass fraction purity was greater than $99 \%$, as confirmed by chromatographic analysis.

Diesel oil was kindly furnished by Lubrificantes e Derivados de Petróleo do Nordeste - LUBNOR, Petrobras S/A. This sample was characterized by determining its density, flash point, kinematic viscosity, distillation temperatures, and molecular weight. Diesel oil used in this study was distilled following the procedure established in ASTM D868. The diesel oil properties are presented in Table 1.

\section{Biodiesel}

In this study, commercial grade edible soybean and coconut oils were used for biodiesel production. Due to their low acidity number (less than $0.5 \mathrm{mg}$ $\mathrm{KOH} \mathrm{g}^{-1}$ ), no pretreatment was needed. The biodiesel samples were obtained by alkaline-catalyzed (potassium methoxide, mass fraction $(\mathrm{w})=0.008$ ) transesterification of soybean oil and coconut oil, respectively, using methanol (supplied from J.T. Baker) as the transesterification alcohol. Methanol in excess, volume fraction $(\varphi)=100 \%$, was used in those reactions at a methanol/oil ratio of $1 / 6$. The resulting phases of glycerine and esters were separated after $12 \mathrm{~h}$ of settling and the resulting ester phase was washed in three steps, as described in earlier works (Feitosa et al., 2010; Mesquita et al., 2011; Nogueira et al., 2010; Santos et al., 2009). The conversion of oil into biodiesel using this technique was greater than $98.2 \pm 1.2 \%$, for both biodiesels.

The basic properties of coconut biodiesel, soybean biodiesel and diesel oil are presented in Table 1. It is worth mentioning that the properties of the biodiesels are within the limits regulated by the USA (ASTM D 6751), European Union (EN 14214), and Brazil (ANP 42), in Standard Resolution No. 7 (Brazilian Regulatory Agency/ANP, 2011).

Table 1: Physicochemical properties of coconut biodiesel, soybean biodiesel, and diesel oil

\begin{tabular}{|c|c|c|c|}
\hline \multirow{2}{*}{ Property } & \multicolumn{2}{|c|}{ Biodiesel } & \multirow{2}{*}{ Diesel oil } \\
\hline & Coconut & Soybean & \\
\hline Density, at $293.15 \mathrm{~K}\left(\mathrm{~kg} / \mathrm{m}^{3}\right)$ & 871.9 & 884.3 & 845.0 \\
\hline Kinematic viscosity, at $313.15 \mathrm{~K}\left(\mathrm{~mm}^{2} / \mathrm{s}\right)$ & 2.45 & 4.674 & 3.161 \\
\hline Flash point $(\mathrm{K})$ & 386.15 & 437.15 & 341.15 \\
\hline Distillation $/ \% / \mathrm{K}$ & & & \\
\hline 10 & - & - & 488.75 \\
\hline 50 & - & - & 548.05 \\
\hline 90 & - & - & 612.25 \\
\hline Molecular weight $(\mathrm{g} / \mathrm{mol})$ & - & - & 184.43 \\
\hline Acidity number $(\mathrm{mg} \mathrm{KOH} / \mathrm{g})$ & 0.0320 & 0.1186 & - \\
\hline Ester content $(\%)$ & 98.2 & $>99.1$ & - \\
\hline Free Glycerine Content (\%) & 0.013 & 0.004 & - \\
\hline Total Glycerine (\%) & 0.072 & 0.154 & - \\
\hline
\end{tabular}


The chemical compositions of the oils, given as the equivalent fatty acid methyl esters (FAME) composition in terms of mass fraction (w), are presented in Table 2. This analysis was obtained by gas chromatography and it revealed that soybean biodiesel is mainly composed of linoleic $(\mathrm{w}=0.5494)$, oleic $(\mathrm{w}=0.2387)$, and palmitic $(\mathrm{w}=0.1132)$ acids. Coconut biodiesel presented lauric acid $(\mathrm{w}=0.3535)$, myristic acid $(\mathrm{w}=0.1984)$, and oleic acid $(\mathrm{w}=0.1430)$ as the constituents of highest concentration.

Table 2: Fatty Acid Methyl Ester (FAME) profile of coconut and soybean biodiesel

\begin{tabular}{|c|c|c|}
\hline \multirow{2}{*}{ Fatty acid } & \multicolumn{2}{|c|}{ Mass fraction (w) of FAME } \\
\cline { 2 - 3 } & Coconut & Soybean \\
\hline C 06:0 & 0.0028 & - \\
C 08:0 & 0.0408 & - \\
C10:0 & 0.0365 & - \\
C12:0 & 0.3535 & - \\
C14:0 & 0.1984 & - \\
C16:0 & 0.1383 & 0.1132 \\
C18:0 & 0.0394 & 0.0313 \\
C18:1 & 0.1430 & 0.2387 \\
C18:2 & 0.0473 & 0.5494 \\
C18:3 & - & 0.0494 \\
C 22:0 & - & 0.0180 \\
\hline
\end{tabular}

\section{Biodiesel Characterization}

The biodiesel samples were characterized according to the procedures and standards dictated by Standard Resolution No. 7 (Brazilian Regulatory Agency/ANP, 2011). The ester content was assayed using a Varian CP-3800 gas chromatography system with a FID (flame ionization detector). The detector temperature was set at $523.15 \mathrm{~K}$ and the injector temperature was set at $473.15 \mathrm{~K}$. The separation column was CP WAX 52CB $30 \mathrm{~m} \mathrm{x} 0.25 \mathrm{~mm} \times$ $0.05 \mu \mathrm{m} \mathrm{DB}$. The temperature was set at $483.15 \mathrm{~K}$.

\section{Viscosity Determination}

Viscosities of the pure liquids and their binary mixtures were measured by using an Anton Paar SVM 3000 digital viscosimeter in a cell containing a tube filled with sample, which rotates at constant speed, as described elsewhere (Feitosa et al., 2010; Nogueira Jr. et al., 2010). The mixtures were prepared by mass using an electronic balance (Tecnal Mark 210 A). All biodiesel blends were prepared in the mass fraction range between $\mathrm{w}=(0.09$ and 0.9$)$, at $298.15 \mathrm{~K}$. The balance has an uncertainty of $0.0001 \mathrm{~g}$. It was ensured that the components were adequately mixed before being transferred to the viscosimeter by stirring the sample tube for about five minutes in a vortex apparatus. Viscosity measurements have an uncertainty of $\pm 0.35 \%$. The temperature in the cell was regulated to $\pm 0.01 \mathrm{~K}$. The uncertainty in mass fractions reported in this work is estimated to be lower than $\pm 1.8 \times 10^{-3}$.

\section{THERMODYNAMIC MODELING}

\section{Viscosity}

The Andrade equation was used for predicting n-hexadecane viscosity (Reid et al., 1987):

$\ln \eta=\mathrm{A}+\frac{\mathrm{B}}{\mathrm{T}}$

where $\mathrm{A}$ and $\mathrm{B}$, characteristic parameters obtained by regression of experimental data, are: $\mathrm{A}=-4.643$; $\mathrm{B}=1700.00$.

For biodiesel viscosity prediction, four models have been applied. The first model was the Yuan model (Yuan et al., 2009), with parameters specific for FAMES (Fatty Acid Methyl Esters). The second model used was the Yuan model with parameters revised by Pratas (Pratas et al., 2010). The equation for these models is:

$\ln \eta=\mathrm{A}+\frac{\mathrm{B}}{\mathrm{T}-\mathrm{T}_{0}}$

where $\mathrm{A}, \mathrm{B}$ and $\mathrm{T}_{0}$ are characteristic parameters for each FAME, $\mathrm{T}$ is the temperature in $\mathrm{K}$ and $\eta$ is the viscosity in $\mathrm{mPa}$. The parameters are shown in Table 3. These models first calculate the viscosity of FAMES, then calculate the biodiesel viscosity from the following equation:

$\ln \eta=\sum_{i=1}^{N} x_{i} \cdot \ln \eta_{i}$

where $\eta$ is the viscosity, $x$ the mole fraction and the subscript " $i$ " indicates the "ith" FAME in the biodiesel. The parameters used to calculate the viscosity of C6:0 were the same as those of C8:0, because characteristic parameters for C6:0 were not found in the literature. 
Table 3: Parameters for the Yuan model and the Yuan model revised by Pratas.

\begin{tabular}{|c|c|c|c|c|c|c|}
\hline \multirow{2}{*}{ FAMES } & \multicolumn{3}{|c|}{ Yuan Model } & \multicolumn{3}{|c|}{ Yuan Model revised by Pratas } \\
\hline & $\mathbf{A}$ & B & T0 & $\mathbf{A}$ & B & T0 \\
\hline C8:0 & -3.742 & 954.946 & 58.467 & -3.476 & 859.303 & 68.948 \\
\hline C10:0 & -3.069 & 697.193 & 110.849 & -3.316 & 814.674 & 93.317 \\
\hline C12:0 & -3.050 & 748.201 & 113.832 & -3.089 & 767.388 & 112.267 \\
\hline C14:0 & -2.851 & 709.099 & 130.364 & -3.124 & 837.282 & 112.358 \\
\hline C16:0 & -2.15 & 507.905 & 167.220 & -2.808 & 746.528 & 132.676 \\
\hline C16:1 & -4.873 & 1865.661 & 0.000 & -2.867 & 748.275 & 118.441 \\
\hline C18:0 & -3.503 & 1091.641 & 97.640 & -2.985 & 876.221 & 122.303 \\
\hline C18:1 & -2.38 & 627.236 & 144.844 & -2.700 & 748.184 & 129.249 \\
\hline C18:2 & -2.373 & 633.578 & 133.942 & -2.618 & 733.236 & 119.641 \\
\hline C18:3 & -2.38 & 652.309 & 124.223 & -2.997 & 904.378 & 91.882 \\
\hline C20:0 & -3.12 & 968.259 & 116.405 & -3.074 & 967.596 & 115.000 \\
\hline C20:1 & -5.283 & 2150.104 & 0.000 & -2.545 & 733.804 & 137.194 \\
\hline $\mathrm{C} 22: 0$ & -3.331 & 1096.881 & 108.071 & -2.528 & 768.64 & 145.057 \\
\hline C22:1 & -5.788 & 2387.303 & 0.000 & -2.409 & 715.397 & 143.268 \\
\hline $\mathrm{C} 24: 0$ & -3.717 & 1316.593 & 91.202 & -2.870 & 951.526 & 127.000 \\
\hline
\end{tabular}

The other models for calculating the biodiesel viscosity are based on the principle of corresponding states, as proposed by do Carmo et al. (2012) using one- and two-reference fluids, Equations (4) and (5), respectively.

$$
\eta=\left(\frac{T_{c, \text { mix }}}{T_{c, 1}}\right)^{1 / 6} \cdot\left(\frac{P_{c, \text { mix }}}{P_{c, 1}}\right)^{2 / 3} \cdot\left(\frac{M W_{\text {mix }}}{M_{1}}\right)^{1 / 2} \cdot \eta_{1}\left(T_{1}, P_{1}\right)
$$

$\eta(T, P)=\frac{\left(\frac{P_{c, \text { mix }}}{P_{c, 1}}\right)^{2 / 3} \cdot\left(\frac{M W_{\text {mix }}}{M W_{1}}\right)^{1 / 2}}{\left(\frac{T_{c, \text { mix }}}{T_{c, 1}}\right)^{1 / 6}} \cdot \eta_{1}\left(T_{1}, P_{1}\right)$

$$
\left[\frac{\left(\frac{\mathrm{P}_{\mathrm{c}, 1}}{\mathrm{P}_{\mathrm{c}, 2}}\right)^{2 / 3} \cdot\left(\frac{\mathrm{MW}_{1}}{\mathrm{MW}_{2}}\right)^{1 / 2}}{\left(\frac{\mathrm{T}_{\mathrm{c}, 1}}{\mathrm{~T}_{\mathrm{c}, 2}}\right)^{1 / 6}} \cdot \frac{\eta_{2}\left(\mathrm{~T}_{2}, \mathrm{P}_{2}\right)}{\eta_{1}\left(\mathrm{~T}_{1}, \mathrm{P}_{1}\right)}\right]^{\mathrm{K}}
$$

where $\mathrm{K}=\frac{\mathrm{MW}_{\text {mix }}-\mathrm{MW}_{1}}{\mathrm{MW}_{2}-\mathrm{MW}_{1}}, \mathrm{~T}_{\mathrm{i}}=\frac{\mathrm{T} \cdot \mathrm{T}_{\mathrm{ci}}}{\mathrm{T}_{\mathrm{c}, \text { mix }}}($ for $\mathrm{i}=1$ or 2$)$ and $\mathrm{T}_{\mathrm{c}}, \mathrm{P}_{\mathrm{c}}$ and $\mathrm{MW}$ are the critical temperature, critical pressure and molecular weight, respectively. The subscript "mix" indicates these properties for the mixture (biodiesel). The subscripts " 1 " and " 2 " indicate the properties of reference fluids. The methyl esters used as reference fluids are: $\mathrm{C} 18: 1$ for the one-reference fluid, and $\mathrm{C} 12: 0$ and $\mathrm{C} 18: 1$ for two-reference fluids. It is important to mention that, for viscosity prediction of reference fluids from the do Carmo models, the Yuan model was used, see Table 4.

Table 4: Parameters for the do Carmo models.

\begin{tabular}{|c|c|c|c|}
\hline \multirow{3}{*}{ Parameter } & $\begin{array}{c}\text { One-reference } \\
\text { fluid model }\end{array}$ & \multicolumn{2}{|c|}{$\begin{array}{c}\text { Two-reference } \\
\text { fluids model }\end{array}$} \\
\cline { 2 - 4 } & C18:1 & \multicolumn{1}{c|}{ C12:0 } & \multicolumn{1}{c|}{ C18:1 } \\
\hline $\mathrm{A}$ & -3.1048 & -2.8777 & -2.8097 \\
$\mathrm{~B}$ & 922.0172 & 648.6797 & 808.3088 \\
$\mathrm{~T}_{0}$ & 105.0185 & 137.6567 & 116.6882 \\
\hline
\end{tabular}

Andrade's equation (Eq. (1)), as proposed by Reid et al. (1987), was used to represent the dynamic viscosity variation with temperature for biodiesel mixtures.

The viscosity deviation, $\Delta \eta$, was calculated from the experimental viscosity data by the RedlichKister polynomial equation (Eq. (6)), as proposed by Redlich and Kister (1987):

$\Delta \eta=\mathrm{w}_{1}\left(1-\mathrm{w}_{1}\right) \sum_{\mathrm{j}=1}^{\mathrm{k}} \mathrm{A}_{\mathrm{j}}\left(1-2 \mathrm{w}_{1}\right)^{\mathrm{j}}$

where $\Delta \eta$ is the viscosity deviation, $\mathrm{w}_{1}$ is the mass fraction of component $1, \mathrm{k}$ is the degree of the polynomial expansion, and $\mathrm{A}_{\mathrm{j}}$ is a parameter.

\section{Critical Properties}

Several properties of methyl esters were estimated using the Marrero-Gani Method (Marrero and Gani, 2001): critical temperature $\left(\mathrm{T}_{\mathrm{c}}\right)$, critical pressure $\left(\mathrm{P}_{c}\right)$, critical volume $\left(\mathrm{V}_{\mathrm{c}}\right)$ and normal boiling temperature $\left(\mathrm{T}_{\mathrm{nb}}\right)$. The acentric factor $(\omega)$ was estimated by the Constantinou-Gani method 
(Constantinou and Gani, 1994). For the estimation of biodiesel critical properties, the Lee-Kesler mixing rules were used, as recommended by Knapp et al. (1982). The explanation and justification for selecting each method can be seen in detail in do Carmo et al. (2012).

\section{RESULTS AND DISCUSSION}

Biodiesels and diesel oil have a multicomponent composition. Nevertheless, it was treated here as a pure pseudocomponent (e.g., the molecular weight of biodiesel was considered to be a weighted average in terms of mass fraction) and the mixtures as pseudobinary mixtures only for the purpose of parameter estimation.

The viscosity of coconut biodiesel was lower than that of diesel oil and other biodiesels, such as colza, soybean, cotton seed, and babassu (Feitosa et al., 2010; Nogueira Jr et al., 2010). According to Nakpong and Wootthikanokkhan (2010), this happens because of the presence of methyl esters of lower molecular weight (C12:0 and C14:0), compared to other biodiesels (see also Table 2).

The parameters (A and B) of Equation (6) and the regression coefficients $\left(\mathrm{R}^{2}\right)$ are given in Table 5. The regression coefficient $\left(\mathrm{R}^{2}\right)$ was better than 0.997.

Viscosity-temperature curves for pure fuels and several blends are shown in Figures 1-4. As can be seen from these figures, the viscosity variation with temperature is similar in the case of biodiesel, diesel oil (or n-hexadecane) and their blends.

Tables 6 and 7 present the measured viscosities $(\eta)$ and the viscosity deviations $(\Delta \eta)$ for the binary mixtures [coconut biodiesel + diesel oil (or n-hexadecane) and soybean biodiesel + diesel oil (or $\mathrm{n}$-hexadecane) $]$ at $\mathrm{T}=(293.15,313.15,333.15$, $353.15,373.15) \mathrm{K}$ and atmospheric pressure, over the entire composition range.

The parameters $A_{i}$, of the Redlich-Kister polynomial Equation (Eq. (6)), obtained by fitting the equations to the experimental values with a least squares algorithm are given in Table 8 , along with the standard deviations $\sigma$, defined as follows:

$\sigma(\Delta \eta)=\sqrt{\frac{\sum\left(\Delta \eta_{\text {exp }}-\Delta \eta_{\text {cal }}\right)^{2}}{(n-p)}}$

where $\Delta \eta_{\exp }$ represents the experimental viscosity deviation, $\Delta \eta_{\text {cal }}$ is the calculated viscosity deviation, $n$ is the number of experimental data and $p$ the order of the related polynomial. The regression coefficient $\left(\mathrm{R}^{2}\right)$ was better than 0.975 for all the studied systems, except for the coconut biodiesel + diesel oil system at $\mathrm{T}=373.15 \mathrm{~K}$, where the $\mathrm{R}^{2}$ value was 0.826 .

Table 5: Estimated parameters at different temperatures from the Andrade Equation (Eq. (1))

\begin{tabular}{|c|c|c|c|}
\hline $\mathbf{w}_{1}$ & $\mathbf{A}$ & B & $\mathbf{R}^{2}$ \\
\hline \multicolumn{4}{|c|}{ Coconut biodiesel + Diesel oil } \\
\hline 0.0000 & -5.7411 & 2110.38 & 0.998 \\
\hline 0.5061 & -5.3771 & 1976.25 & 0.998 \\
\hline 0.9030 & -5.2136 & 1920.89 & 0.999 \\
\hline 1.0000 & -5.1743 & 1908.19 & 0.999 \\
\hline \multicolumn{4}{|c|}{ Coconut biodiesel + n-Hexadecane } \\
\hline 0.0000 & -5.2842 & 1907.21 & 0.999 \\
\hline 0.5242 & -5.1745 & 1879.51 & 0.999 \\
\hline 0.9111 & -5.1657 & 1898.73 & 0.999 \\
\hline 1.0000 & -5.1743 & 1908.18 & 0.999 \\
\hline \multicolumn{4}{|c|}{ Soybean biodiesel + Diesel oil } \\
\hline 0.0000 & -5.7442 & 2112.36 & 0.997 \\
\hline 0.2050 & -5.5963 & 2092.51 & 0.998 \\
\hline 0.4097 & -5.4927 & 2086.13 & 0.998 \\
\hline 0.6079 & -5.3899 & 2080.87 & 0.998 \\
\hline 0.8088 & -5.3212 & 2086.33 & 0.998 \\
\hline 1.0000 & -5.2493 & 2090.86 & 0.998 \\
\hline \multicolumn{4}{|c|}{ Soybean biodiesel + n-Hexadecane } \\
\hline 0.0000 & -5.2842 & 1907.21 & 0.999 \\
\hline 0.2202 & -5.2230 & 1918.05 & 0.999 \\
\hline 0.4319 & -5.1948 & 1946.55 & 0.999 \\
\hline 0.6315 & -5.1993 & 1987.62 & 0.999 \\
\hline 0.8208 & -5.2203 & 2037.87 & 0.998 \\
\hline 1.0000 & -5.2462 & 2088.86 & 0.998 \\
\hline
\end{tabular}




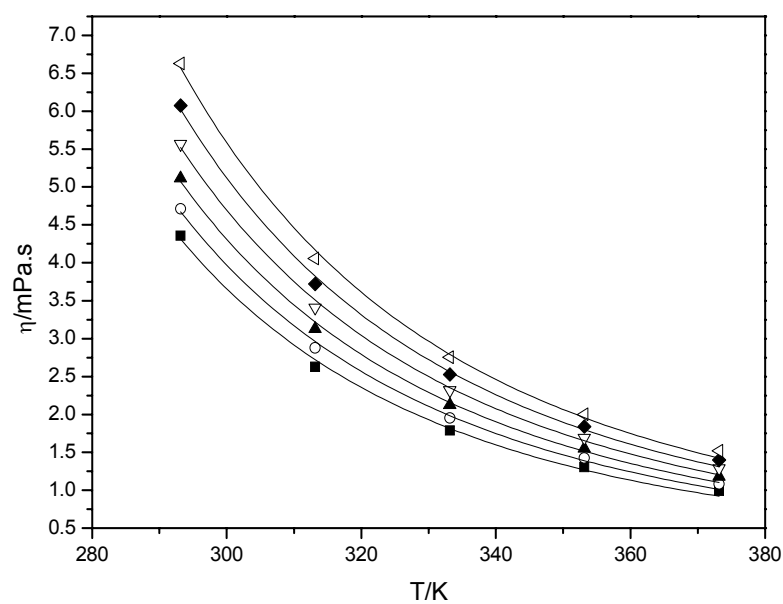

Figure 1: Temperature dependence of dynamic viscosity for blends of soybean biodiesel + diesel oil. (๓) Pure diesel oil. (o) Blend of $20.50 \%$ of soybean biodiesel. (A) Blend of $40.97 \%$ of soybean biodiesel. ( $\nabla$ ) Blend of $60.79 \%$ of soybean biodiesel. (•) Blend of $80.88 \%$ of soybean biodiesel. $(\Delta)$ Pure soybean biodiesel. Over the temperature range 293.15-373.15 K; data fitted to Andrade's equation.

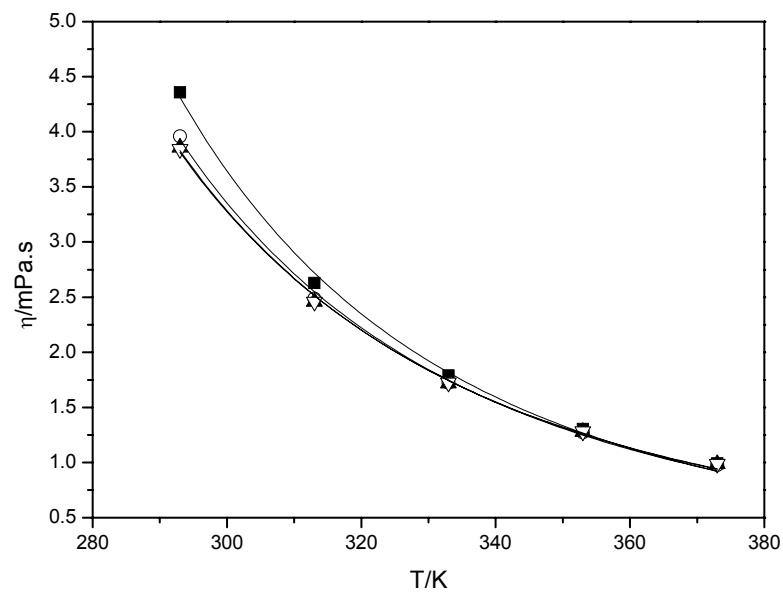

Figure 3: Temperature dependence of dynamic viscosity for blends of Coconut Biodiesel + Diesel Oil, (-) Pure Diesel Oil. (o) Blend of $50,61 \%$ of Coconut Biodiesel. (ム) Blend of $90,30 \%$ of Coconut Biodiesel. ( $\nabla)$ Pure Coconut Biodiesel. Over the Temperature Range 293.15$373.15 \mathrm{~K}$; data fitted to Andrade's equation.

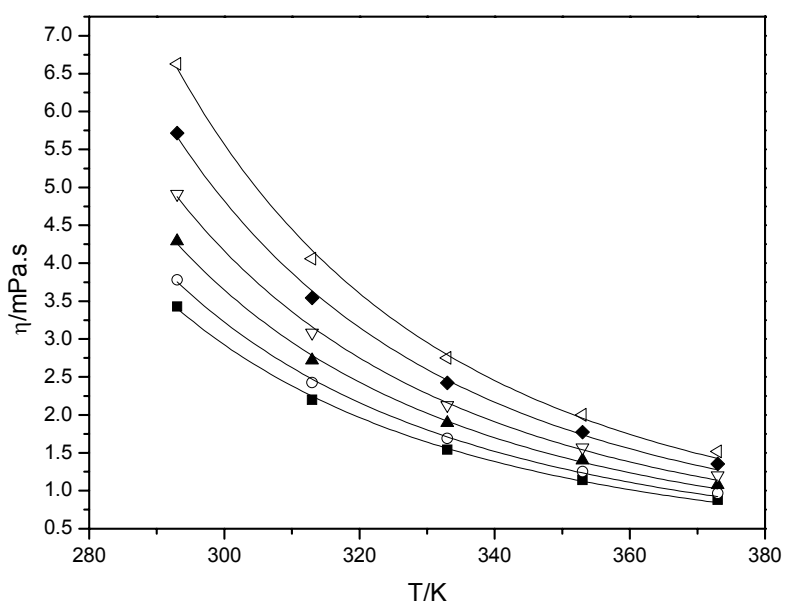

Figure 2: Temperature dependence of dynamic viscosity for blends of soybean biodiesel $+n$ hexadecane. (๘) Pure n-hexadecane. (o) Blend of $22.02 \%$ of soybean biodiesel. (A) Blend of $43.19 \%$ of soybean biodiesel. ( $\nabla$ ) Blend of $63.15 \%$ of soybean biodiesel. (•) Blend of $82.08 \%$ of soybean biodiesel. $(\triangle)$ Pure soybean biodiesel. Over the temperature range 293.15$373.15 \mathrm{~K}$; data fitted to Andrade's equation.

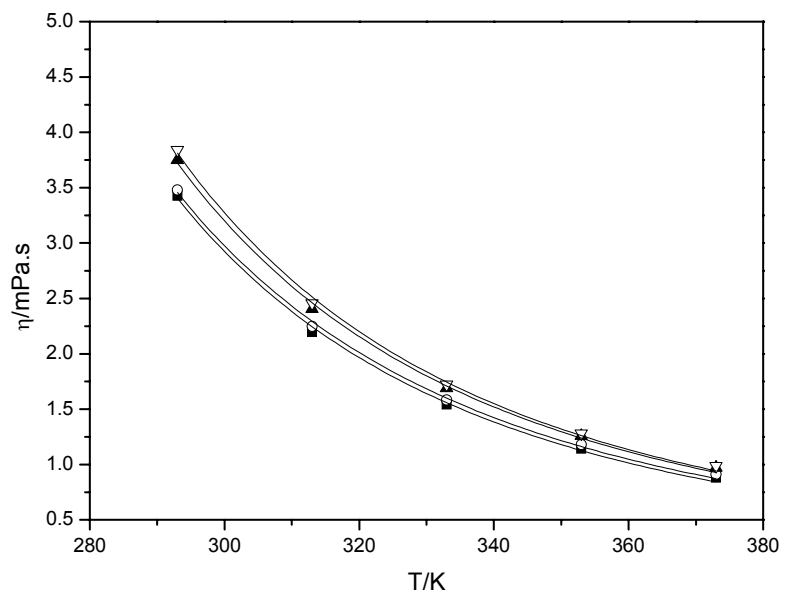

Figure 4: Temperature effect on dynamic viscosity for blends of Coconut Biodiesel $+\mathrm{n}$-Hexadecane, (๓) Pure n-Hexadecane. (o) Blend of 52.42\% of Coconut Biodiesel. (A) Blend of $91.11 \%$ of Coconut Biodiesel. ( $\nabla)$ Pure Coconut Biodiesel. Over the temperature range 293.15-373.15 K, lines calculated from Andrade's equation. 
Table 6: Dynamic viscosity, $\eta$, and viscosity deviation, $\Delta \eta$, for the binary mixtures $\left(w_{1}\right.$ coconut biodiesel + $\left(1-w_{1}\right)$ n-hexadecane), $\left(w_{1}\right.$ coconut biodiesel $+\left(1-w_{1}\right)$ diesel oil), $\left(w_{1}\right.$ soybean biodiesel $+\left(1-w_{1}\right)$ n-hexadecane), and $\left(w_{1}\right.$ soybean biodiesel $+\left(1-w_{1}\right)$ diesel oil) at temperatures ranging from $T=(293.15$ to 373.15) $\mathrm{K}$.

\begin{tabular}{|c|c|c|c|c|c|}
\hline \multirow{2}{*}{$\mathbf{w}_{1}$} & \multicolumn{5}{|c|}{ Temperature/K } \\
\hline & 293.15 & 313.15 & 333.15 & 353.15 & 373.15 \\
\hline \multicolumn{6}{|c|}{ Coconut biodiesel + n-hexadecane } \\
\hline \multicolumn{6}{|c|}{$\eta / \mathbf{m P a} . \mathbf{s}$} \\
\hline 0.1077 & 3.3973 & 2.1874 & 1.5378 & 1.1438 & 0.8803 \\
\hline 0.2195 & 3.3985 & 2.1942 & 1.5452 & 1.1512 & 0.8878 \\
\hline 0.3236 & 3.4014 & 2.1979 & 1.5482 & 1.1547 & 0.8909 \\
\hline 0.4316 & 3.4353 & 2.2192 & 1.5630 & 1.1661 & 0.9002 \\
\hline 0.5242 & 3.4811 & 2.2464 & 1.5817 & 1.1797 & 0.9101 \\
\hline 0.6256 & 3.5361 & 2.2795 & 1.6039 & 1.1961 & 0.9235 \\
\hline 0.7261 & 3.6020 & 2.3193 & 1.6311 & 1.2161 & 0.9393 \\
\hline 0.8171 & 3.6709 & 2.3591 & 1.6577 & 1.2344 & 0.9526 \\
\hline 0.9111 & 3.7518 & 2.4055 & 1.6883 & 1.2578 & 0.9718 \\
\hline \multicolumn{6}{|c|}{$\Delta \eta / \mathrm{mPa} . \mathrm{s}$} \\
\hline 0.1077 & -0.0762 & -0.0384 & -0.0221 & -0.0146 & -0.0119 \\
\hline 0.2195 & -0.1212 & -0.0607 & -0.0351 & -0.0226 & -0.0164 \\
\hline 0.3236 & -0.1612 & -0.0840 & -0.0511 & -0.0335 & -0.0245 \\
\hline 0.4316 & -0.1719 & -0.0907 & -0.0560 & -0.0370 & -0.0268 \\
\hline 0.5242 & -0.1643 & -0.0875 & -0.0542 & -0.0362 & -0.0268 \\
\hline 0.6256 & -0.1511 & -0.0807 & -0.0504 & -0.0338 & -0.0243 \\
\hline 0.7261 & -0.1267 & -0.0670 & -0.0416 & -0.0277 & -0.0192 \\
\hline 0.8171 & -0.0953 & -0.0508 & -0.0316 & -0.0219 & -0.0157 \\
\hline 0.9111 & -0.0532 & -0.0288 & -0.0181 & -0.0115 & -0.0067 \\
\hline \multicolumn{6}{|c|}{ Coconut biodiesel + diesel oil } \\
\hline \multicolumn{6}{|c|}{$\eta / m P a . s$} \\
\hline 0.1048 & 4.2402 & 2.6039 & 1.7779 & 1.2997 & 0.9913 \\
\hline 0.2045 & 4.1673 & 2.5719 & 1.7601 & 1.2871 & 0.9803 \\
\hline 0.2962 & 4.0962 & 2.5444 & 1.7509 & 1.2879 & 0.9857 \\
\hline 0.3995 & 4.0198 & 2.5116 & 1.7349 & 1.2792 & 0.9802 \\
\hline 0.5061 & 3.9593 & 2.4870 & 1.7231 & 1.2721 & 0.9765 \\
\hline 0.5971 & 3.9201 & 2.4715 & 1.7171 & 1.2711 & 0.9759 \\
\hline 0.7043 & 3.8899 & 2.4640 & 1.7171 & 1.2742 & 0.9807 \\
\hline 0.8071 & 3.8694 & 2.4588 & 1.7174 & 1.2760 & 0.9828 \\
\hline 0.9030 & 3.8585 & 2.4593 & 1.7186 & 1.2779 & 0.9864 \\
\hline \multicolumn{6}{|c|}{$\Delta \eta / \mathrm{mPa} . \mathrm{s}$} \\
\hline 0.1048 & -0.0623 & -0.0069 & -0.0032 & -0.0019 & -0.0012 \\
\hline 0.2045 & -0.0839 & -0.0218 & -0.0145 & -0.0122 & -0.0117 \\
\hline 0.2962 & -0.1078 & -0.0336 & -0.0177 & -0.0094 & -0.0058 \\
\hline 0.3995 & -0.1310 & -0.0487 & -0.0270 & -0.0158 & -0.0108 \\
\hline 0.5061 & -0.1367 & -0.0551 & -0.0318 & -0.0205 & -0.0140 \\
\hline 0.5971 & -0.1290 & -0.0550 & -0.0318 & -0.0195 & -0.0141 \\
\hline 0.7043 & -0.1040 & -0.0441 & -0.0248 & -0.0140 & -0.0087 \\
\hline 0.8071 & -0.0716 & -0.0317 & -0.0178 & -0.0099 & -0.0061 \\
\hline 0.9030 & -0.0331 & -0.0147 & -0.0103 & -0.0059 & -0.0020 \\
\hline
\end{tabular}


Table 7: Dynamic viscosity, $\eta$, and viscosity deviation, $\Delta \eta$, for the binary mixtures $\left(w_{1}\right.$ soybean biodiesel + $\left(1-w_{1}\right)$ n-hexadecane), and ( $w_{1}$ soybean biodiesel $+\left(1-w_{1}\right)$ diesel oil) at temperatures ranging from $T=(293.15$ to 373.15) $K$

\begin{tabular}{|c|c|c|c|c|c|}
\hline \multirow{2}{*}{$\mathbf{w}_{1}$} & \multicolumn{5}{|c|}{ Temperature/K } \\
\hline & 293.15 & 313.15 & 333.15 & 353.15 & 373.15 \\
\hline \multicolumn{6}{|c|}{ Soybean biodiesel + n-hexadecane } \\
\hline \multicolumn{6}{|c|}{$\eta / \mathrm{mPa} . \mathrm{s}$} \\
\hline 0.1099 & 3.5876 & 2.2975 & 1.6077 & 1.1917 & 0.9144 \\
\hline 0.2202 & 3.7803 & 2.4246 & 1.6883 & 1.2523 & 0.9641 \\
\hline 0.3268 & 4.0137 & 2.5570 & 1.7849 & 1.3234 & 1.0185 \\
\hline 0.4319 & 4.2904 & 2.7205 & 1.8922 & 1.4005 & 1.0766 \\
\hline 0.5309 & 4.5687 & 2.8840 & 1.9988 & 1.4754 & 1.1321 \\
\hline 0.6315 & 4.9145 & 3.0847 & 2.1301 & 1.5677 & 1.2013 \\
\hline 0.7248 & 5.2845 & 3.2983 & 2.2679 & 1.6643 & 1.2734 \\
\hline 0.8208 & 5.7141 & 3.5426 & 2.4239 & 1.7730 & 1.3528 \\
\hline 0.9129 & 6.1775 & 3.8045 & 2.5899 & 1.8877 & 1.4369 \\
\hline \multicolumn{6}{|c|}{$\Delta \eta / \mathrm{mPa} . \mathrm{s}$} \\
\hline 0.1099 & -0.1930 & -0.1048 & -0.0658 & -0.0459 & -0.0364 \\
\hline 0.2202 & -0.3531 & -0.1828 & -0.1188 & -0.0797 & -0.0570 \\
\hline 0.3268 & -0.4606 & -0.2487 & -0.1514 & -0.0998 & -0.0706 \\
\hline 0.4319 & -0.5201 & -0.2806 & -0.1714 & -0.1127 & -0.0795 \\
\hline 0.5309 & -0.5584 & -0.3012 & -0.1848 & -0.1226 & -0.0871 \\
\hline 0.6315 & -0.5343 & -0.2876 & -0.1754 & -0.1164 & -0.0821 \\
\hline 0.7248 & -0.4627 & -0.2475 & -0.1506 & -0.0996 & -0.0695 \\
\hline 0.8208 & -0.3402 & -0.1817 & -0.1110 & -0.0731 & -0.0513 \\
\hline 0.9129 & -0.1713 & -0.0911 & -0.0566 & -0.0372 & -0.0260 \\
\hline \multicolumn{6}{|c|}{ Soybean biodiesel + diesel oil } \\
\hline \multicolumn{6}{|c|}{$\eta /$ mPa.s } \\
\hline 0.1017 & 4.5416 & 2.7663 & 1.8781 & 1.3672 & 1.0402 \\
\hline 0.2050 & 4.7143 & 2.8757 & 1.9535 & 1.4233 & 1.0826 \\
\hline 0.3054 & 4.9065 & 2.9976 & 2.0360 & 1.4830 & 1.1300 \\
\hline 0.4097 & 5.1155 & 3.1273 & 2.1253 & 1.5486 & 1.1801 \\
\hline 0.5134 & 5.3414 & 3.2653 & 2.2187 & 1.6157 & 1.2320 \\
\hline 0.6079 & 5.5680 & 3.4101 & 2.3177 & 1.6904 & 1.2888 \\
\hline 0.7103 & 5.8320 & 3.5691 & 2.4229 & 1.7652 & 1.3438 \\
\hline 0.8088 & 6.0749 & 3.7194 & 2.5248 & 1.8375 & 1.3995 \\
\hline 0.9071 & 6.3608 & 3.8957 & 2.6440 & 1.9226 & 1.4627 \\
\hline \multicolumn{6}{|c|}{$\Delta \eta / \mathrm{mPa} . \mathrm{s}$} \\
\hline 0.1017 & -0.0459 & -0.0078 & -0.0079 & -0.0074 & -0.0063 \\
\hline 0.2050 & -0.1077 & -0.0460 & -0.0321 & -0.0232 & -0.0182 \\
\hline 0.3054 & -0.1435 & -0.0676 & -0.0464 & -0.0333 & -0.0235 \\
\hline 0.4097 & -0.1714 & -0.0869 & -0.0577 & -0.0403 & -0.0282 \\
\hline 0.5134 & -0.1810 & -0.0971 & -0.0642 & -0.0453 & -0.0308 \\
\hline 0.6079 & -0.1690 & -0.0873 & -0.0563 & -0.0364 & -0.0236 \\
\hline 0.7103 & -0.1375 & -0.0746 & -0.0498 & -0.0328 & -0.0224 \\
\hline 0.8088 & -0.1183 & -0.0650 & -0.0429 & -0.0290 & -0.0185 \\
\hline 0.9071 & -0.0556 & -0.0292 & -0.0184 & -0.0123 & -0.0069 \\
\hline
\end{tabular}


Table 8: Estimated parameters for viscosity deviation $(\Delta \eta)$ of the binary mixtures ( $w_{1}$ coconut biodiesel + $\left(1-w_{1}\right)$ n-hexadecane), $\left(w_{1}\right.$ coconut biodiesel $+\left(1-w_{1}\right)$ diesel oil), $\left(w_{1}\right.$ soybean biodiesel $+\left(1-w_{1}\right)$ n-hexadecane), and $\left(w_{1}\right.$ soybean biodiesel $+\left(1-w_{1}\right)$ diesel oil $)$, at different temperatures, along with the standard deviation $(\sigma)$.

\begin{tabular}{|c|c|c|c|c|c|c|}
\hline Function & $\mathbf{T} / \mathbf{K}$ & $\mathbf{A}_{\mathbf{0}}$ & $\mathbf{A}_{1}$ & $\mathbf{A}_{2}$ & $\sigma / \mathbf{m P a} . \mathbf{s}$ & $\mathbf{R}^{2}$ \\
\hline \multicolumn{7}{|c|}{ Coconut biodiesel + n-Hexadecane } \\
\hline$\Delta \eta / \mathrm{mPa} . \mathrm{s}$ & $\begin{array}{l}293.15 \\
313.15 \\
333.15 \\
353.15 \\
373.15 \\
\end{array}$ & $\begin{array}{l}-0.6737 \\
-0.3571 \\
-0.2212 \\
-0.1471 \\
-0.1072 \\
\end{array}$ & $\begin{array}{l}0.0954 \\
0.0344 \\
0.0102 \\
0.0024 \\
0.0084 \\
\end{array}$ & $\begin{array}{l}-0.0506 \\
-0.0425 \\
0.0126 \\
0.0106 \\
0.0121 \\
\end{array}$ & $\begin{array}{l}0.0034 \\
0.0027 \\
0.0017 \\
0.0011 \\
0.0012 \\
\end{array}$ & $\begin{array}{l}0.998 \\
0.997 \\
0.995 \\
0.994 \\
0.989 \\
\end{array}$ \\
\hline \multicolumn{7}{|c|}{ Coconut biodiesel + Diesel oil } \\
\hline$\Delta \eta / \mathrm{mPa} . \mathrm{s}$ & $\begin{array}{l}293.15 \\
313.15 \\
333.15 \\
353.15 \\
373.15\end{array}$ & $\begin{array}{l}-0.5381 \\
-0.2191 \\
-0.1236 \\
-0.0750 \\
-0.0521\end{array}$ & $\begin{array}{c}0.0653 \\
-0.0614 \\
-0.0378 \\
-0.0151 \\
0.0003\end{array}$ & $\begin{array}{l}0.0911 \\
0.1541 \\
0.0769 \\
0.0453 \\
0.0344\end{array}$ & $\begin{array}{l}0.0057 \\
0.0009 \\
0.0015 \\
0.0022 \\
0.0025\end{array}$ & $\begin{array}{l}0.990 \\
0.999 \\
0.988 \\
0.929 \\
0.826\end{array}$ \\
\hline \multicolumn{7}{|c|}{ Soybean biodiesel + n-Hexadecane } \\
\hline$\Delta \eta / \mathrm{mPa} . \mathrm{s}$ & $\begin{array}{l}293.15 \\
313.15 \\
333.15 \\
353.15 \\
373.15 \\
\end{array}$ & $\begin{array}{l}-2.2105 \\
-1.1914 \\
-0.7272 \\
-0.4798 \\
-0.3377 \\
\end{array}$ & $\begin{array}{l}0.2485 \\
0.1398 \\
0.0673 \\
0.0387 \\
0.0161\end{array}$ & $\begin{array}{c}0.1414 \\
0.1147 \\
0.0343 \\
0.0077 \\
-0.0127 \\
\end{array}$ & $\begin{array}{l}0.0390 \\
0.0220 \\
0.0107 \\
0.0064 \\
0.0035\end{array}$ & $\begin{array}{l}0.999 \\
0.999 \\
0.998 \\
0.997 \\
0.995 \\
\end{array}$ \\
\hline \multicolumn{7}{|c|}{ Soybean biodiesel + Diesel oil } \\
\hline$\Delta \eta / \mathrm{mPa} . \mathrm{s}$ & $\begin{array}{l}293.15 \\
313.15 \\
333.15 \\
353.15 \\
373.15 \\
\end{array}$ & $\begin{array}{l}-0.7148 \\
-0.3764 \\
-0.2481 \\
-0.1698 \\
-0.1159 \\
\end{array}$ & $\begin{array}{l}-0.0550 \\
-0.1019 \\
-0.0542 \\
-0.0221 \\
-0.0004 \\
\end{array}$ & $\begin{array}{l}0.1328 \\
0.1757 \\
0.0966 \\
0.0572 \\
0.0348 \\
\end{array}$ & $\begin{array}{l}0.0060 \\
0.0053 \\
0.0034 \\
0.0028 \\
0.0020 \\
\end{array}$ & $\begin{array}{l}0.994 \\
0.983 \\
0.984 \\
0.977 \\
0.975 \\
\end{array}$ \\
\hline
\end{tabular}

Figures 5 to 8 show the viscosity deviations, $\Delta \eta$, calculated by using the Redlich-Kister polynomial equation, as described above. An interesting finding was that, for all systems and temperatures studied, the $\Delta \eta$ values presented a negative trend. It was also

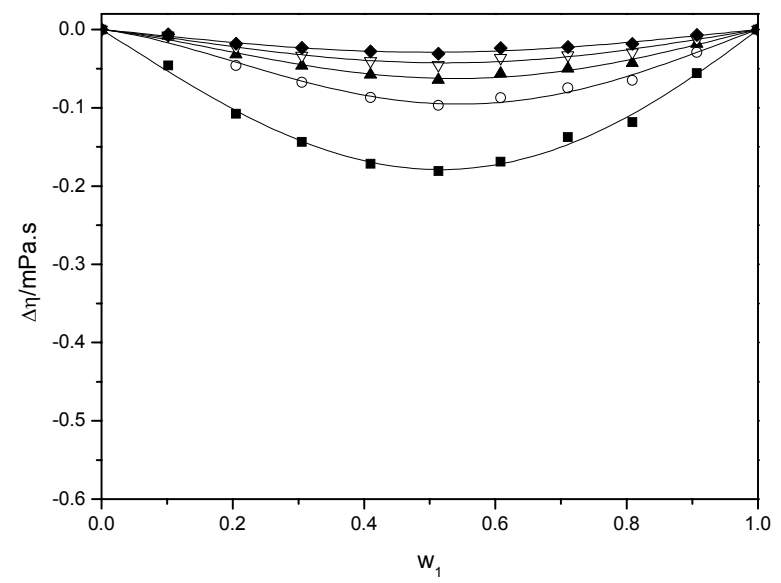

Figure 5: Deviation of dynamic viscosity versus the mass fraction of the binary mixtures (Soybean Biodiesel + Diesel Oil). At $\mathrm{T}=293.15 \mathrm{~K}(\mathbf{\bullet})$; $313.15 \mathrm{~K}(\mathrm{o}) ; 333.15 \mathrm{~K}(\mathbf{\Delta}) ; 353.15 \mathrm{~K}(\nabla) ; 373.15 \mathrm{~K}$ $(\bullet)$. Lines are calculated from Redlich-Kister Polynomials. observed that the viscosity increases with increasing temperature. The negative viscosity deviation for all the studied mixtures could be interpreted as indicating that the attractive forces between molecules are stronger than the repulsion forces.

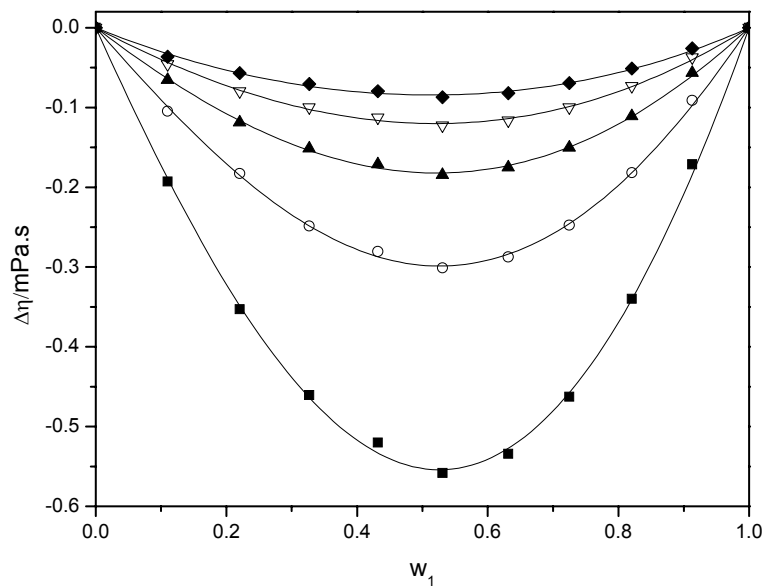

Figure 6: Deviation of dynamic viscosity versus the mass fraction of the binary mixtures (Soybean Biodiesel + n-Hexadecane). At $\mathrm{T}=293.15 \mathrm{~K}(\mathbf{-})$; 313.15 K (o); $333.15 \mathrm{~K}(\mathbf{\Delta})$; $353.15 \mathrm{~K}(\mathrm{\nabla}) ; 373.15 \mathrm{~K}$ $(\bullet)$. Lines are calculated from Redlich-Kister Polynomials. 


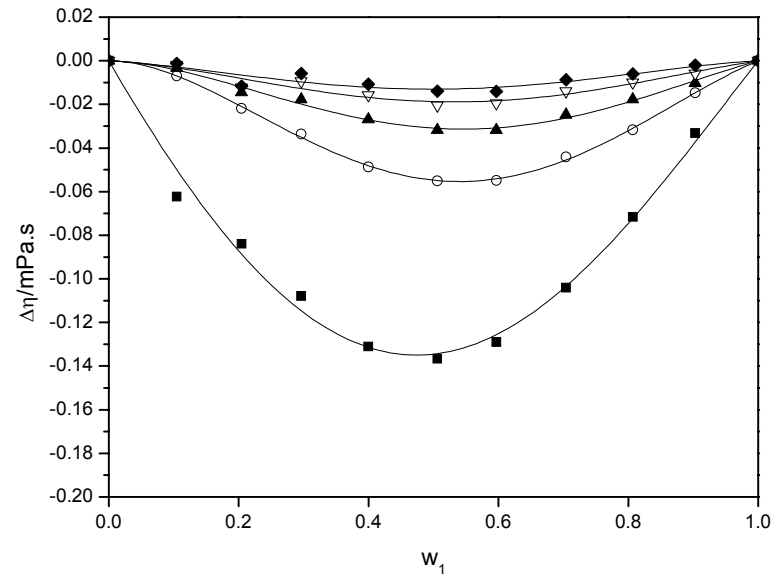

Figure 7: Deviation of dynamic viscosity versus the mass fraction of the binary mixtures (Coconut Biodiesel + n-Hexadecane). At $\mathrm{T}=293.15 \mathrm{~K}(\mathbf{\bullet})$; $313.15 \mathrm{~K}(\mathrm{o}) ; 333.15 \mathrm{~K}(\mathbf{\Delta}) ; 353.15 \mathrm{~K}(\mathrm{\nabla}) ; 373.15 \mathrm{~K}$ $(\bullet)$. Lines are calculated from Redlich-Kister Polynomials.

Table 9 presents the global comparison between the experimental and estimated viscosity using different models for coconut biodiesel, soybean biodiesel and n-hexadecane. While Table 10 presents the global comparison between experimental and estimated viscosity for the biodiesel $/ \mathrm{n}$-hexadecane blends using the Vogel equation for n-hexadecane and the do Carmo model. It can be observed from

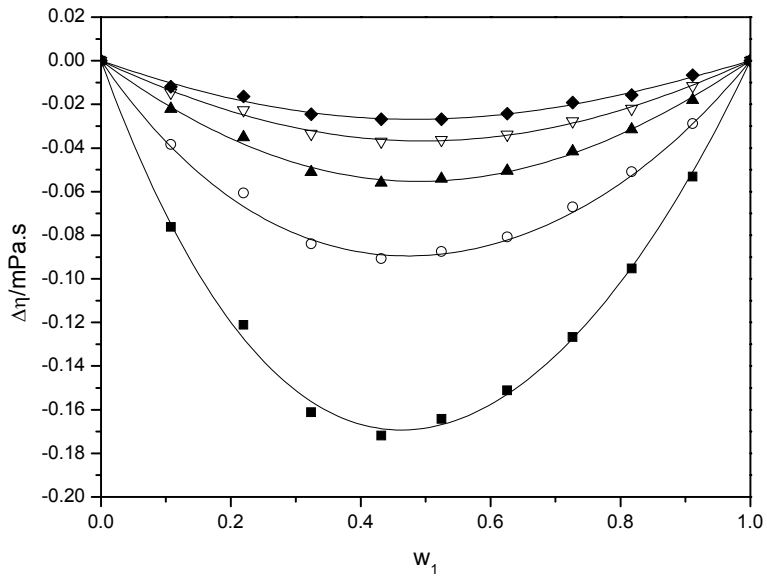

Figure 8: Deviation of dynamic viscosity versus the mass fraction of the binary mixtures (Coconut Biodiesel + Diesel Oil). At $\mathrm{T}=293.15 \mathrm{~K}(\mathbf{-})$; 313.15 K (o); $333.15 \mathrm{~K}$ (४); $353.15 \mathrm{~K}$ ( $\nabla) ; 373.15 \mathrm{~K}$ $(\bullet)$. Lines are calculated from Redlich-Kister Polynomials.

these tables that the do Carmo model with one reference fluid gives the lowest average relative deviation (ARD) between experimental and calculated values, with $4.48 \%$ for biodiesel, followed by the do Carmo two-reference fluids model (5.69\%), the Yuan model $(6.75 \%)$ and the Revised Yuan model (7.15\%). The ARD for the Andrade equation for $n$-hexadecane was $3.63 \%$.

Table 9: Global comparison between experimental viscosity data and predictive models

\begin{tabular}{|c|c|c|c|c|c|c|c|c|c|c|c|c|}
\hline & \multicolumn{4}{|c|}{ S.D. } & \multicolumn{4}{|c|}{ AAD } & \multicolumn{4}{|c|}{ ARD (\%) } \\
\hline & $O Y^{a}$ & $\mathbf{R Y} \mathbf{b}^{\mathbf{b}}$ & $\mathrm{C1}^{\mathrm{c}}$ & $\mathrm{C2}^{\mathrm{d}}$ & $O Y^{\mathbf{a}}$ & $\mathbf{R Y} \mathbf{b}^{\mathbf{b}}$ & $\mathrm{C1}^{\mathrm{c}}$ & $\mathrm{C2}^{\mathrm{d}}$ & $O Y^{a}$ & $\mathbf{R Y} \mathbf{Y}^{\mathbf{b}}$ & $\mathrm{C1}^{\mathrm{c}}$ & $\mathrm{C2}^{\mathrm{d}}$ \\
\hline Coconut Biodiesel & 0.01 & 0.04 & 0.09 & 0.19 & 0.01 & 0.04 & 0.06 & 0.13 & 0.46 & 1.55 & 2.69 & 4.87 \\
\hline Soybean Biodiesel & 0.57 & 0.55 & 0.27 & 0.29 & 0.47 & 0.45 & 0.22 & 0.24 & 12.94 & 12.41 & 6.26 & 6.52 \\
\hline Total & 0.40 & 0.39 & 0.20 & 0.24 & 0.24 & 0.25 & 0.14 & 0.18 & 6.75 & 7.15 & 4.48 & 5.69 \\
\hline \multirow[b]{3}{*}{ n-Hexadecane } & \multicolumn{4}{|c|}{ S.D. } & \multicolumn{4}{|c|}{ AAD } & \multicolumn{4}{|c|}{ ARD (\%) } \\
\hline & \multicolumn{4}{|c|}{ Vogel Equation } & \multicolumn{4}{|c|}{ Vogel Equation } & \multicolumn{4}{|c|}{ Vogel Equation } \\
\hline & \multicolumn{4}{|c|}{0.12} & \multicolumn{4}{|c|}{0.07} & \multicolumn{4}{|c|}{3.63} \\
\hline
\end{tabular}

${ }^{\mathrm{a}}$ Original Yuan Model; ${ }^{\mathrm{b}}$ Revised Yuan Model by Pratas ; ${ }^{\mathrm{c}} \mathrm{Carmo}$ with one reference fluid; ${ }^{\mathrm{d}} \mathrm{Carmo}$ with two reference fluids.

S.D. $=\sqrt{\sum\left(\mathrm{X}_{\text {est }}-\mathrm{X}_{\mathrm{exp}}\right)^{2} / \mathrm{N}} ; \mathrm{AAD}=1 / \mathrm{N} \sum\left|\mathrm{X}_{\mathrm{est}}-\mathrm{X}_{\mathrm{exp}}\right| ; \mathrm{ARD}(\%)=1 / \mathrm{N} \sum\left|\left(\mathrm{X}_{\mathrm{est}}-\mathrm{X}_{\text {exp }}\right) / \mathrm{X}_{\text {exp }}\right| \times 100$

Table 10: Global comparison between experimental viscosity data and predictive data using the Vogel equation and the do Carmo one-fluid model for mixtures: Coconut Biodiesel + n-Hexadecane (Mixture 1) and Soybean Biodiesel + n-Hexadecane (Mixture 2)

\begin{tabular}{|c|c|c|c|c|c|}
\hline \multicolumn{2}{|c|}{ S.D. } & \multicolumn{2}{c|}{ AAD } & \multicolumn{2}{c|}{ ARD (\%) } \\
\hline Mixture 1 & Mixture 2 & Mixture 1 & Mixture 2 & Mixture 1 & Mixture 2 \\
\hline 0.07 & 0.11 & 0.07 & 0.09 & 4.18 & 4.10 \\
\hline
\end{tabular}

S.D. $=\sqrt{\sum\left(\mathrm{X}_{\mathrm{est}}-\mathrm{X}_{\mathrm{exp}}\right)^{2} / \mathrm{N}} ; \mathrm{AAD}=1 / \mathrm{N} \sum\left|\mathrm{X}_{\mathrm{est}}-\mathrm{X}_{\mathrm{exp}}\right| ; \mathrm{ARD}(\%)=1 / \mathrm{N} \sum\left|\left(\mathrm{X}_{\mathrm{est}}-\mathrm{X}_{\mathrm{exp}}\right) / \mathrm{X}_{\mathrm{exp}}\right| \times 100$ 
Figure 9 presents a comparative analysis between experimental data for coconut and soybean biodiesel and the estimated viscosity for the do Carmo model with one reference fluid.

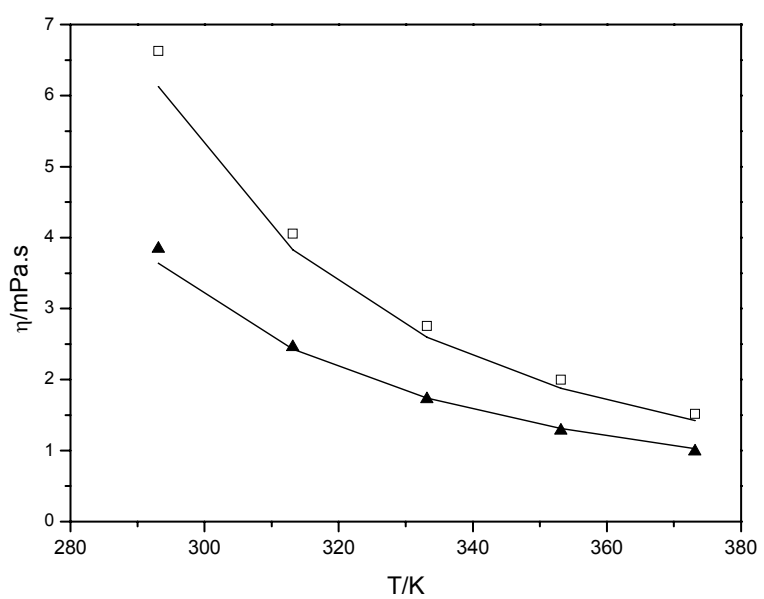

Figure 9: Comparison between experimental data $[(\mathbf{\Delta})$ for Coconut Biodiesel and ( $\square$ ) for Soybean Biodiesel] and the do Carmo one-reference fluid model (solid line).

Figure 10 presents the experimentally determined viscosity variation with temperature for coconut biodiesel $+\mathrm{n}$-hexadecane mixtures and that predicted using the Vogel equation (for n-hexadecane) and the do Carmo model with one reference fluid (for biodiesel). The use of Andrade's equation (for n-hexadecane) and the do Carmo one-reference fluid model (for biodiesel) with Eq. (5) gives good accuracy for the blends, as shown in Table 10.

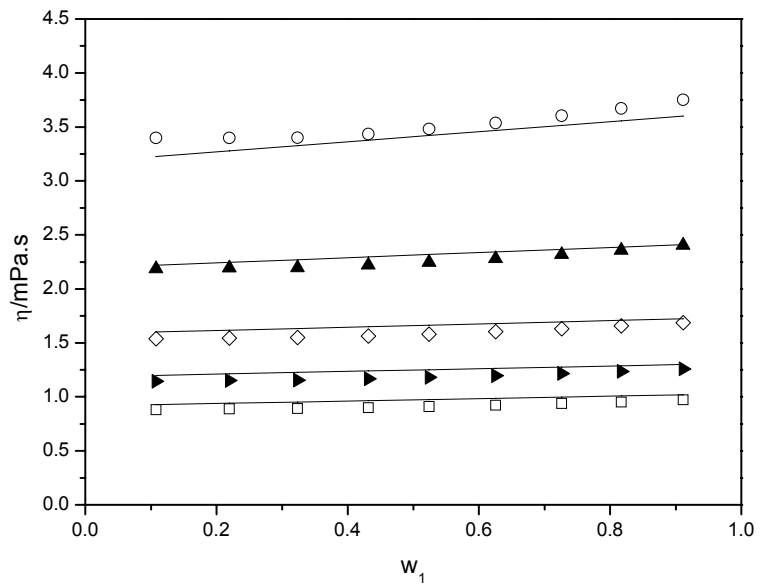

Figure 10: Comparison between experimental data (symbols) and the estimated viscosity using the Vogel equation + do Carmo one-fluid model (solid line) for the blend between Coconut Biodiesel (1) + n-Hexadecane (2). (O) $\mathrm{T}=293.15 \mathrm{~K}$; ( $\mathbf{\Delta}) \mathrm{T}=313.15 \mathrm{~K}$; (॰) $\mathrm{T}=333.15 \mathrm{~K} ;(\bullet) \mathrm{T}=353.15 \mathrm{~K} ;($ ( ) $\mathrm{T}=373.15 \mathrm{~K}$.

\section{CONCLUSIONS}

An Anton Paar SVM 3000 digital viscosimeter was used to measure the viscosities of four binary mixtures [soybean biodiesel + diesel oil (or $\mathrm{n}$-hexadecane) and coconut biodiesel + diesel oil (or $\mathrm{n}$-hexadecane)], in the range of 293.15 to $373.15 \mathrm{~K}$ and at atmospheric pressure. From these experimental data, it could be observed that important errors are introduced by using n-hexcadecane as the sole molecule representing diesel oil, especially in lumping procedures. For this reason, we warn the readers which respect to its use. Additionally, the experimental viscosity deviations, $\Delta \eta$, were calculated by using the Redlich-Kister polynomial equation. In all cases, negative values of the viscosity deviations were found, indicating that attractive forces among molecules are stronger than the repulsion forces. Of the viscosity prediction models studied, the do Carmo one-reference fluid model presents the best results, with an ARD equal to $4.48 \%$. This model presented good results when used with Andrade's equation (for n-hexadecane) for viscosity prediction calculations of (biodiesel $+n-$ hexadecane) blends.

\section{ACKNOWLEDGEMENTS}

The financial support by $\mathrm{CNPq}$ (Conselho Nacional de Desenvolvimento Científico e Tecnológico, Brazil), Brazilian National Agency of Petroleum, Natural Gas and Biofuels (Agência Nacional do Petróleo, Gás Natural e Biocombustíveis - ANP), and CTPetro/FINEP (Financiadora de Estudos e Projetos) is gratefully acknowledged.

\section{NOMENCLATURE}

A, B, C specific parameters

$\mathrm{A}_{\mathrm{j}} \quad$ parameter

MW molecular weight

$\mathrm{P}_{\mathrm{c}} \quad$ critical pressure

$\mathrm{T}$ temperature

$\mathrm{T}_{\mathrm{c}} \quad$ critical temperature

$\mathrm{T}_{\mathrm{nb}} \quad$ normal boiling temperature

$\mathrm{V}_{\mathrm{c}} \quad$ critical volume

$\eta \quad$ dynamic viscosity

$\mathrm{w}$ mass fraction

$\omega \quad$ acentric factor

$\Delta \eta \quad$ viscosity deviation

$\Delta \eta_{\text {cal }} \quad$ viscosity deviation based on predicted data 
viscosity deviation based on experimental data

$\sigma \quad$ standard deviations

$\varphi \quad$ volume fraction

\section{REFERENCES}

Benjumea, P., Agudelo, J. and Agudelo, A., Basic properties of palm oil biodiesel-diesel blends. Fuel, 87, 2069-2075 (2008).

Boletim mensal do biodiesel, http://www.anp.gov.br/ $? \mathrm{pg}=21986 \& \mathrm{~m}=\& \mathrm{t} 1=\& \mathrm{t} 2=\& \mathrm{t} 3=\& \mathrm{t} 4=\& \mathrm{ar}=\& \mathrm{ps}=$ $\&$ cachebust $=1271786737218$ (Accessed in January 20, 2011). (In Portuguese).

Brazilian Regulatory Agency (Standard Resolution No. 7, de 19.3.2008), http://www.anp.gov.br/ petro/legis biodieselasp (Accessed in January 20, 2011). (In Portuguese).

Constatinou, L. and Gani R., New group contribution method for estimating properties of pure compounds. AIChE J., 40, 10, 1697-1710 (1994).

do Carmo, F. R., Sousa, Jr. P. M., Aguiar-Santiago, R. S., de Sant'Ana, H. B., Development of a new model for biodiesel viscosity prediction based on the principle of corresponding state. Fuel, 92, 250-257 (2012).

Encinar, J. M., Gonzalez J. F. and RodriquezReinares A., Biodiesel from used frying oil variables affecting the yields and characteristics of the biodiesel. Ind. Eng. Chem. Res., 44, 54915499 (2005).

Feitosa, F. X., Rodrigues, M. L., Veloso, C. B., Cavalcante, C. L., Albuquerque, M. C. G. and de Sant'Ana, H. B., Viscosities and densities of binary mixtures of coconut + colza and coconut + soybean biodiesel at various temperatures. J. Chem. Eng. Data, 55, 3909-3914 (2010).

Jha, S. K., Fernando, S. and Filip, T. S. D., Flame temperature analysis of biodiesel blends and components. Fuel, 87, 1982-1988 (2008).

Knapp, H., Doring, R., Oellrich, L., Plocker, U. and Prausnitz, J. M., Vapor-liquid equilibria for mixtures of low boiling substances. Chem. Data Ser., VI, DECHEMA (1982).
Knothe, G. and Van Gerpen, J. H., The Biodiesel Handbook, 2nd Ed., AOCS Publishing, Urbana (2009).

Marrero, J. and Gani, R., Group-contribution based estimation of pure component properties. Fluid Phase Equilibria, 183-184, 183-208 (2001).

Mesquita, F. M. R., Feitosa, F. X., Santiago-Aguiar, R. S. and de Sant'Ana, H. B., Density, excess volumes, and partial volumes of binary mixtures of soybean biodiesel + diesel and soybean biodiesel $+n$-hexadecane at different temperatures and atmospheric pressure. J. Chem. Eng. Data, 56, 153-157 (2011).

Nakpong, P. and Wootthikanokkhan, S., High free fatty acid coconut oil as a potential feedstock for biodiesel production in Thailand. Renewable Energy, 35, 1682-1687 (2010).

Nogueira, Jr. C. A., Feitosa, F. X., Fernandes, F. A. N., Santiago, R. S. and de Sant'Ana, H. B., Densities and viscosities of binary mixtures of babassu biodiesel + cotton seed or soybean biodiesel at different temperatures. J. Chem. Eng. Data, 55, 5305-5310 (2010).

Pratas, M. J., Freitas, S., Oliveira, M. B., Monteiro, S. C., Lima, A. S. and Coutinho, J. A. P., Densities and viscosities of fatty acid methyl and ethyl esters. J. Chem. Eng. Data, 55, 3983-3990 (2010).

Redlich, O. and Kister, A. T., Thermodynamics of non-electrolyte solutions, $\mathrm{x}$-y-t relations in a binary system. Ind. Eng. Chem., 40, 341-345 (1948).

Reid, R. C., Prausnitz, J. M. and Poling, B. E., The Properties of Gases and Liquids, 4th Ed., McGraw-Hill, Boston, MA (1987).

Santos, F. F. P., Rodrigues, S., Fernandes, F. A. N. Optimization of the production of biodiesel from soybean oil by ultrasound assisted methanolysis. Fuel Process. Technol., 90, 312-316 (2009).

Tate, R. E., Watts, K. C. Allen C. A. W. and Wilkie, K. I., The viscosities of three biodiesel fuels at temperatures up to $300{ }^{\circ} \mathrm{C}$. Fuel, 85, 1010-1015 (2006).

Yuan, W., Hansen, A. C., Zhang, Q., Predicting the temperature dependent viscosity of biodiesel fuels. Fuel, 88, 1120-1126 (2009). 